\title{
Compatibility and stability of valsartan in a solid pharmaceutical formulation
}

\author{
Tamíris Amanda Júlioㅁ, Igor Fernando Zâmara1 ${ }^{1}$, Jerusa Simone Garcia ${ }^{1}$, \\ Marcello Garcia Trevisan ${ }^{1,2, *}$
}

\begin{abstract}
${ }^{1}$ Laboratory of Pharmaceutical Analysis and Characterization, Institute of Chemistry, Federal University of Alfenas, Alfenas, MG, Brazil, ${ }^{2}$ National Institute of Science and Technology of Bioanalytical, State University of Campinas, Campinas, SP, Brazil
\end{abstract}

\begin{abstract}
Valsartan (VAL) is a highly selective blocker of the angiotensin II receptor that has been widely used in the treatment of hypertension. Active pharmaceutical ingredient compatibility with excipients (crospovidone, hypromellose, magnesium stearate, microcrystalline cellulose and titanium dioxide) is usually evaluated in solid pharmaceutical development. Compatibility and stability can be evaluated by liquid chromatography. Studies were performed using binary mixtures of 1:1 (w/w) VAL/excipient; samples were stored under accelerated stability test conditions $\left(40{ }^{\circ} \mathrm{C}\right.$ at $75 \%$ relative humidity). The results indicate that VAL is incompatible with crospovidone and hypromellose, which reduced the VAL content and gave rise to new peaks in the chromatogram due to degradation products.
\end{abstract}

Uniterms: Valsartan/compatibility. Valsartan/stability. Hypertension/treatment. Differential Scanning Calorimetry/drug analysis. High performance liquid chromatography/quantitative analysis. Pharmaceutical formulations/quantitative analysis..

Valsartana (VAL) é um bloqueador altamente seletivo do receptor da angiotensina II, que tem sido amplamente utilizado para o tratamento da hipertensão. Testes de compatibilidade com excipientes usualmente empregados em formulações sólidas são utilizados no desenvolvimento de formulações sólidas. Neste trabalho, realizaram-se testes utilizando misturas binárias na proporção $1: 1(\mathrm{~m} / \mathrm{m}) \mathrm{de}$ VAL/excipiente e as amostras foram armazenadas em condições de estabilidade acelerada $\left(40{ }^{\circ} \mathrm{C} \mathrm{em}\right.$ $75 \%$ de umidade relativa). Os resultados obtidos indicam a incompatibilidade de VAL com crospovidona e hipromelose, através da redução do teor de VAL e a presença de novos picos no cromatograma provenientes de produtos de degradação.

Unitermos: Valsartana/compatibilidade. Valtasan/estabilidade. Hipertensão/tratamento. Calorimetria Exploratória Diferencial/análise de fármacos. Cromatografia líquida de alto desempenho/análise quantitativa.

\section{INTRODUCTION}

Hypertension is a chronic medical condition that is the world's leading cause of mortality (Lewington et al, 2002; Lotufo, 2005), affecting people of varying ages and economic status. To minimize or prevent hypertension, adequate diet and physical exercise are recommended. Many different medicines can be used to treat high blood

\footnotetext{
*Correspondence: M. G. Trevisan. Laboratório de Análise e Caracterização de Fármacos - LACFar, Instituto de Química, Universidade Federal de Alfenas, 37130-000 - Alfenas - MG, Brasil. E-mail: trevisan@unifal-mg.edu.br
}

pressure, including angiotensin II receptor antagonists such as valsartan (VAL), also known as $N$-(1-oxopentyl)$N$-[2'-(1H-tetrazol- 5-yl) [1,1'-biphenyl]-4-yl]methyl]L-valine (Celebier et al., 2010). This medication is generally prescribed in high doses (approximately 40 to $320 \mathrm{mg}$ daily) for continuous use. Interactions between VAL and excipients can contribute to the formation of degradation products, which may potentially be toxic or alter bioavailability. Consequently, these interactions may affect the safety and efficacy of VAL in solid formulations.

Pre-formulation testing, an important step in the development of new products or the reformulation of 
existing ones, includes the chemical characterization of the drug and analytical compatibility/stability tests (Gibson, 2004). In pharmaceutical industry, an active pharmaceutical ingredient (API) is subjected to pre-formulation studies, which provide the necessary information for the development of a stable drug formulation with adequate bioavailability (Blasko et al., 2001).

A drug is rarely administered in isolation; in most cases, it is associated with a variety of adjuvants and excipients (diluents, disintegrants, lubricants) to ensure adequate absorption, to increase stability and to improve appearance. Although excipients are often considered inert, it is known that they can interact with APIs, changing their stability, absorption and bioavailability. Therefore, an effective pharmaceutical formulation depends on the selection of suitable excipients (Mura et al., 2005; Stulzer et al., 2008). To investigate the compatibility of the components of a formulation, techniques such as X-ray diffraction, infrared spectroscopy, high performance liquid chromatography (HPLC) and thermal analysis (especially differential scanning calorimetry (DSC)) are used (Almeida et al., 2010; Julio et al., 2012; Slavio et al., 2009; Verma et al., 2004). Differential scanning calorimetry is a fast and reliable technique for use in pharmaceutical compatibility tests (Júlio et al., 2012; Oliveira et al., 2011; Verma et al., 2005); however, only crystalline samples show a sharp and strong endothermic event related to melting. Amorphous (non-crystalline materials) do not show these endothermic events. Materials that exhibit fusion followed by decomposition (such as hydrochloride salts) are difficult to evaluate in this way and should be tested by non-thermal methods (Late et al., 2008; Liltorp et al., 2011). Thus, solid-state characterization of APIs should be performed before pre-formulation evaluation or compatibility studies. However, to ensure accurate and reliable results, it is necessary to determine the most appropriate and sensitive technique for a specific API through validated stability-indicating methods.

Another factor that should be considered in drug development is stability, which is evaluated through the detection of degradation products. The API is combined with the proposed excipients and submitted to an accelerated stability chamber, according to International Conference on Harmonization (ICH) methods. Humidity has significant effects on drugs if reactive species are present in the formulation, potentially leading to physical or chemical modification (such as hydrolysis or hydrate formation) (Adami, Waterman, 2005). Drug stability guidelines (Q1A-Q1F) require that formulation stability tests be performed under accelerated and long-term conditions (ICH, 2003). These tests provide information about drug shelf life and permit detection/quantification of degradation products.

The present study investigated the compatibility of VAL with excipients commonly used in solid pharmaceutical formulation. We also conducted accelerated stability tests following $\mathrm{ICH}$ recommendations using direct contact with humidity and heat. The chemical interactions of VAL in binary mixtures were investigated by HPLC. X-Ray diffraction, DSC and thermogravimetric (TG) data were also obtained during solid-state characterization of VAL.

\section{MATERIAL AND METHODS}

\section{Samples and reagents}

Valsartan (Dr. Reddys, India (batch AFEH002828)) and USP grade excipients (crospovidone, hypromellose, magnesium stearate, microcrystalline cellulose and titanium dioxide) were donated by Aché Pharmaceutical (Brazil). HPLC grade acetonitrile was obtained from JT Baker (USA); glacial acetic acid was obtained from Sigma-Aldrich (Brazil). De-ionized water for HPLC analysis was prepared using a Millipore Direct-Q 3UV water purification system (Millipore, France). Other reagents were of analytical grade and were used without further purification.

\section{Accelerated stability study}

Stability testing was performed using VAL alone and in binary mixtures with each excipient in a $1: 1(\mathrm{~m} / \mathrm{m})$ ratio. For stability studies, VAL and excipients were weighed in $4 \mathrm{~mL}$ glass vials $(n=3)$, homogenized using two stainless steel balls $(3 \mathrm{~mm})$ and then vortex-mixed for one minute at $25 \mathrm{~Hz}$. After preparation, the steel balls were removed, and the samples were stored for one month in a stability chamber at $40 \pm 0.5^{\circ} \mathrm{C} / 75 \pm 1 \%$ relative humidity $(\mathrm{RH})$ in open containers (direct contact with humidity).

\section{Differential Scanning Calorimetry Analysis (DSC)}

Thermal analysis of VAL was conducted using a high sensitivity DSC calorimeter (model EXSTAR X-DSC7020, SII Nanotechnology Inc., Japan) equipped with a microscope. Samples (approximately $4 \mathrm{mg}$ ) were encapsulated in hermetically sealed aluminum pans. All experiments were performed under a nitrogen flow of $50 \mathrm{~mL} \mathrm{~min}-1$ at a heating rate of $10^{\circ} \mathrm{C} \mathrm{min}^{-1}$ from 20 to $350{ }^{\circ} \mathrm{C}$. An indium standard with purity of more than $99.99 \%$ was used for temperature calibration. 


\section{Thermogravimetric Analysis (TG)}

A TG curve was obtained employing a thermobalance (model SDT Q600, TA Instruments, USA) in a temperature range of 25 to $600{ }^{\circ} \mathrm{C}$, using alumina crucibles containing samples of approximately $4 \mathrm{mg}$ under a flow of $\mathrm{N}_{2}$ $\left(100 \mathrm{~mL} \mathrm{~min}^{-1}\right)$ at a heating rate of $10^{\circ} \mathrm{C} \mathrm{min}^{-1}$. The TG/DTA equipment was calibrated using an indium standard for temperature and an alumina calibration weight for mass.

\section{Powder X-ray diffraction (PXRD)}

Diffractograms were obtained in a Powder X-ray diffractometer (model Ultima IV, Rigaku, Japan) using a $\mathrm{CuK} \alpha$ tube $(1.5418 \AA)$ at a voltage of $40 \mathrm{kV}$ and a current of $30 \mathrm{~mA}$ in the range of 5 to $55\left({ }^{\circ} 2 \theta\right)$.

\section{High performance liquid chromatography (HPLC)}

The quantification of VAL in each mixture submitted at $40{ }^{\circ} \mathrm{C}$ and $75 \%$ RH was performed using HPLC according to the relevant monograph in the US Pharmacopeia (USP $32,2009)$. The samples were prepared by diluting binary mixtures with the mobile phase $\left(0.45 \mathrm{mg} \mathrm{mL}^{-1}\right.$ of VAL), sonicating for $15 \mathrm{~min}$ and filtering through $0.45 \mu \mathrm{m}$ filters before HPLC analysis. The HPLC system used in this work was composed of an online degasser (DGU-20A5), liquid chromatograph (LC-20AT), auto sampler (SIL20A), photodiode array (PDA) detector (SPD-M20A) set to $273 \mathrm{~nm}$ and LC Solutions software version 1.21 SP1 (Shimadzu, Japan). Briefly, the pharmacopeia method involves isocratic elution with a Hypersil ODS C18 column (Waters, USA) $(5 \mu \mathrm{m}, 3.0 \mathrm{~mm} \times 12.5 \mathrm{~cm})$ at $25^{\circ} \mathrm{C}$ using a mobile phase of water, acetonitrile and glacial acetic acid (500:500:1). The injection volume was $10 \mu \mathrm{L}$ and the flow rate was $0.4 \mathrm{~mL} \mathrm{~min}^{-1}$. After appropriate

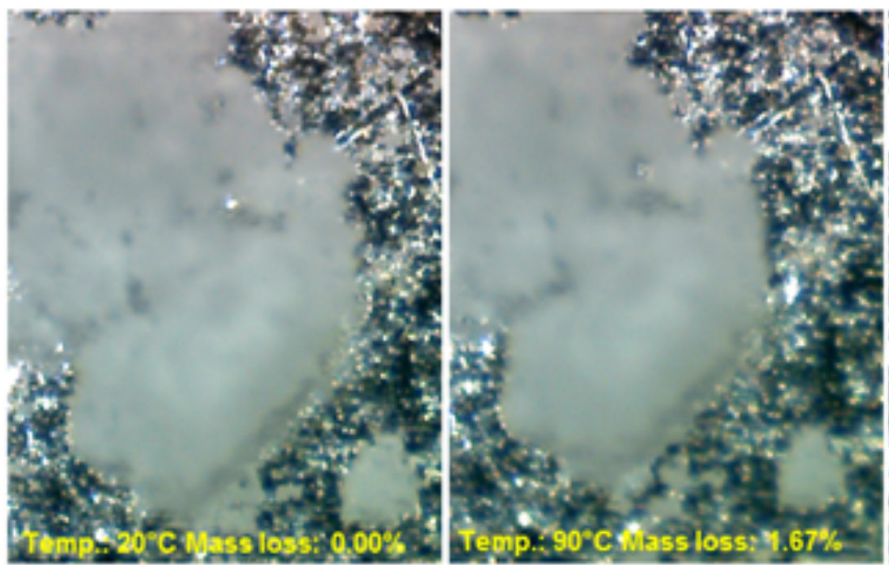

dilution, the samples were analyzed using HPLC and the VAL content determined from the calibration curve prepared over the expected range ( 0.1 to $\left.0.9 \mathrm{mg} \mathrm{mL}^{-1}\right)$.

\section{RESULTS AND DISCUSSION}

\section{Analytical technique}

VAL was characterized using both thermal analysis and PXRD. VAL showed two endothermic peaks at $70.5{ }^{\circ} \mathrm{C}\left(\Delta \mathrm{H}=4.04 \mathrm{~J} \mathrm{~g}^{-1}\right)$ and $99.1{ }^{\circ} \mathrm{C}\left(\Delta \mathrm{H}=8.09 \mathrm{~J} \mathrm{~g}^{-1}\right)$ and an exothermic peak with $\mathrm{T}_{\text {onset }}=165.3^{\circ} \mathrm{C}$ related to the beginning of decomposition. The TG curve showed two principal mass reduction events, with DTG peaks at $211.7^{\circ} \mathrm{C}$ and $408.9^{\circ} \mathrm{C}$ (Figure 1). Only the first endothermic event $\left(70.5{ }^{\circ} \mathrm{C}\right)$ resulted in a mass reduction of $1.67 \%$ in the TG analysis, presumably due to residual solvents. The second endothermic event was investigated using imaging-DSC. The results are shown in Figure 2, indicating melting of VAL at $\mathrm{T}_{\text {onset }}=94.2^{\circ} \mathrm{C}$ and $\mathrm{T}_{\text {endset }}=102.8^{\circ} \mathrm{C}$. In Figure 3 , the powder X-ray diffractogram of VAL reveals

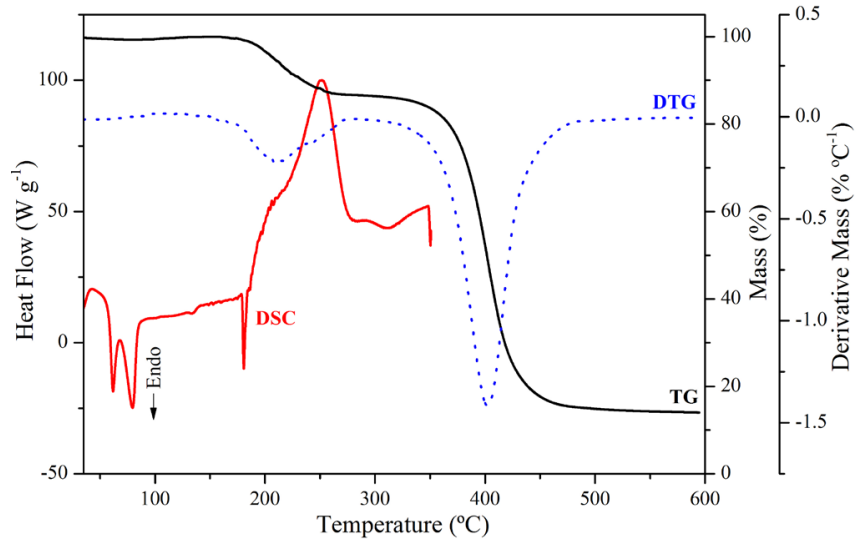

FIGURE 1 - DSC and TG curve of VAL.

FIGURE 2 - Imaging-DSC photomicrographs of VAL.

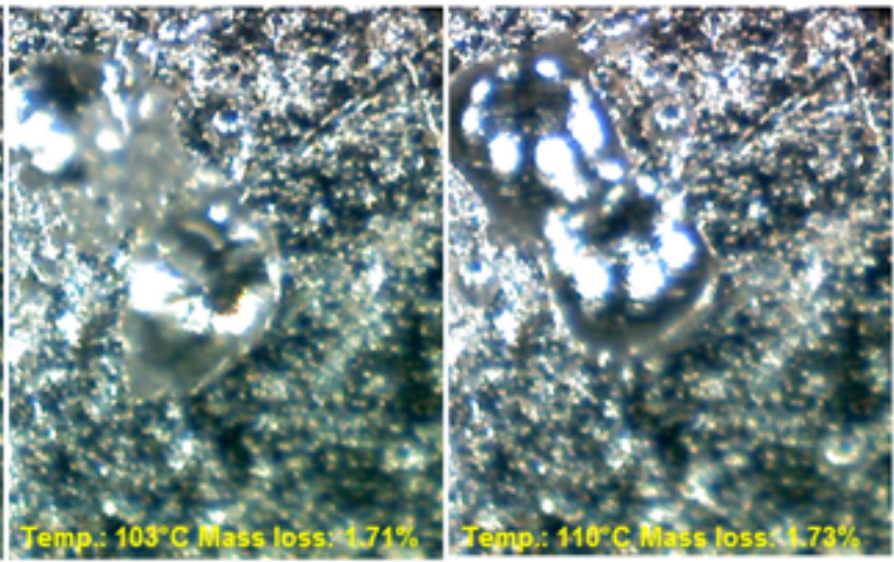




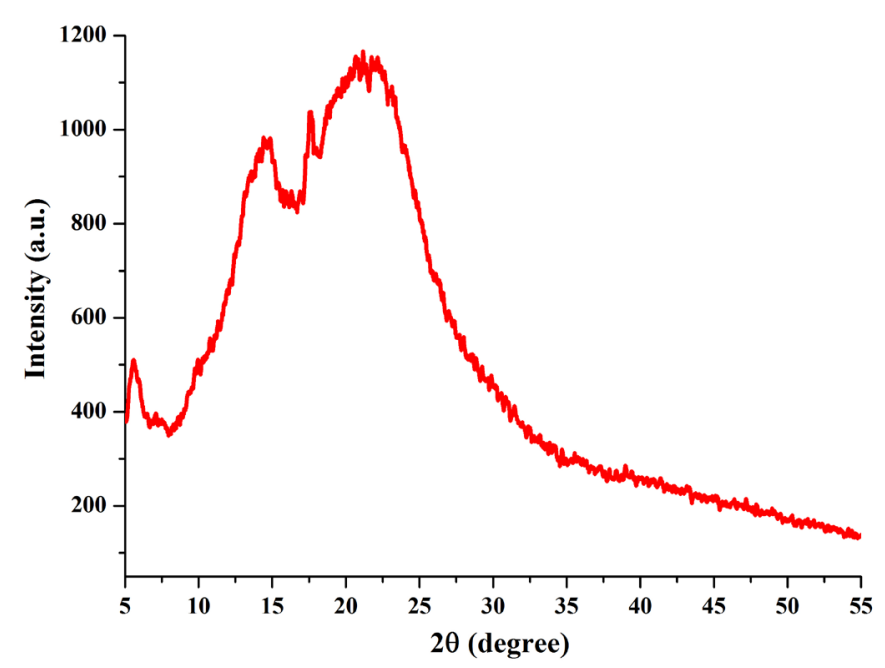

FIGURE 3 - Powder X-ray diffractogram of VAL.

no crystallographic peaks, suggesting that the material was amorphous. Hence, the VAL used in this study was amorphous and did not show any thermal events, preventing the use of DSC for compatibility evaluation.

Thermal analysis has the advantage of responding to analytes in an ambient environment suitable for the acceleration of degradation reactions. When such methods cannot be employed, non-thermal methods such as liquid chromatography or spectroscopy are the most sensitive and suitable techniques. However, there are no immediate reactions between the API and excipients when contact is established. Therefore, these methods must be combined with storage (humidity and heat) to accelerate degradation or API-excipient reactions.

Although liquid chromatography is considered slow due to the complexity of some samples, it is able to offer qualitative and quantitative indications of API degradation when stability-indicating methods are employed. Several
HPLC-UV methods for the determination of VAL have been described in the literature (Agrahari et al., 2009; Celebier et al., 2010; Krishnaiah et al., 2010) but have not been used to test VAL's stability and compatibility with excipients.

\section{Stability and compatibility assay}

The evaluation of the stability and compatibility of VAL and its binary mixtures after one month at $40{ }^{\circ} \mathrm{C}$ and $75 \% \mathrm{RH}$ was conducted using the HPLC-UV method described in the relevant USP monograph (USP 32, 2009). The response was linear within the range studied $\left(\mathrm{R}^{2}=0.9882\right)$. The HPLC-UV method for quantitation of VAL can detect thermal degradation and chemical interactions with excipients, which decrease the concentration of VAL (Table I).

The chromatograms for VAL before and after the stability study are illustrated in Figure 4. In this analysis,

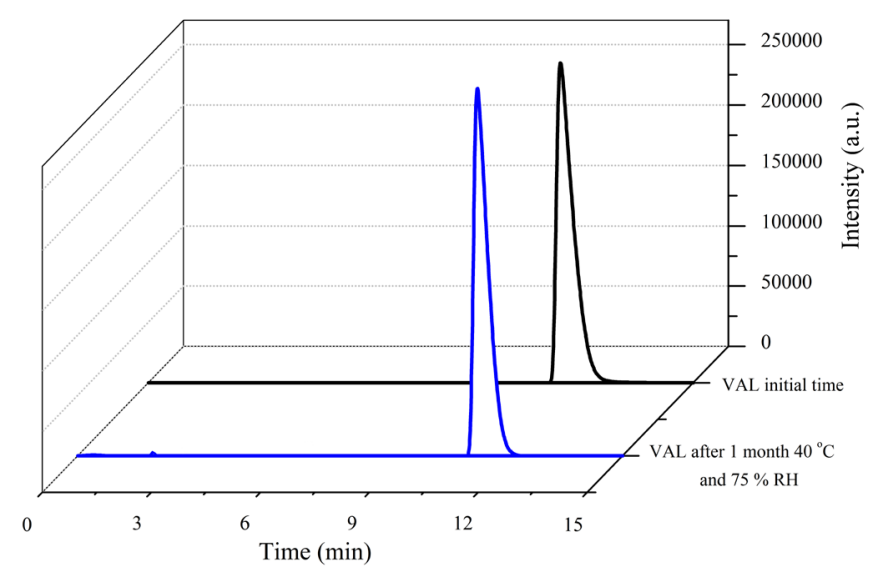

FIGURE 4 - HPLC chromatogram of VAL before and after 1 month at $40{ }^{\circ} \mathrm{C}$ and $75 \% \mathrm{RH}$.

TABLE I - HPLC data from VAL and binary mixtures after one month at $40{ }^{\circ} \mathrm{C}$ and $75 \% \mathrm{RH}(n=3)$

\begin{tabular}{lccccc}
\hline Sample & $\begin{array}{c}\text { Area average } \pm \\
\text { standard deviation } \\
\left(\times 10^{6}\right)\end{array}$ & $\begin{array}{c}\text { Observed } \\
\left(\mathrm{mg} \mathrm{mL}^{-1}\right)^{\mathrm{a}}\end{array}$ & $\begin{array}{c}\text { \% of } \\
\text { degradation }\end{array}$ & $\begin{array}{c}\text { Impurity a } \\
\text { (Area average } \pm \\
\text { standard } \\
\left.\text { deviation, } \times 10^{6}\right)\end{array}$ & $\begin{array}{c}\text { Impurity b } \\
\text { (Area average } \pm \\
\text { standard } \\
\left.\text { deviation, } \times 10^{6}\right)\end{array}$ \\
\hline VAL (Initial time) & $8.555 \pm 0.004$ & $0.45 \pm 0.02$ & - & - & - \\
VAL (After one month) & $8.523 \pm 0.006$ & $0.45 \pm 0.03$ & 0.36 & - & - \\
VAL + Crospovidone & $7.865 \pm 0.009$ & $0.42 \pm 0.05$ & 9.17 & $0.57 \pm 0.02$ & - \\
VAL + Hypromellose & $8.0170 \pm 0.0007$ & $0.413 \pm 0.003$ & 8.20 & - & $0.340 \pm 0.003$ \\
VAL + Magnesium stearate & $8.5350 \pm 0.0003$ & $0.449 \pm 0.001$ & 0.23 & - & - \\
VAL + Microcrystalline cellulose & $8.489 \pm 0.001$ & $0.45 \pm 0.05$ & 0.74 & - & - \\
VAL + Titanium dioxide & $8.5270 \pm 0.0004$ & $0.449 \pm 0.002$ & 0.31 & - & - \\
\hline
\end{tabular}

${ }^{a}$ Observed concentration $=\left(\right.$ Area $\left.+0.450 \times 10^{6}\right) / 2 \times 10^{7}$

b $\%$ of degradation $=($ Initial concentration - Final concentration/ Initial concentration $) \times 100$ 
no alteration in the chromatographic profile was observed between samples; there were no peaks from degradation products. The reduction in VAL concentration was quite small (approximately $0.36 \%$, see Table I), which indicates that there was no significant change in the amount of API after the accelerated stability assay. Therefore, moisture and heat are not important factors in promoting the degradation of VAL in isolation.

The chromatograms of VAL and binary mixtures (microcrystalline cellulose, titanium dioxide and magnesium stearate) are shown in Figure 5. No alteration in peak area was detected, indicating that these excipients have sufficient compatibility for use in solid formulations of VAL.

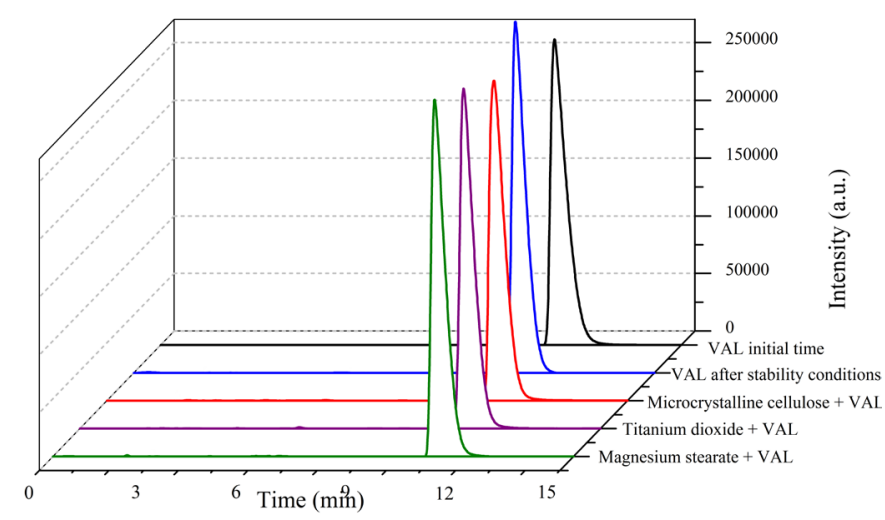

FIGURE 5 - HPLC chromatogram of VAL before storage and of binary mixtures with microcrystalline cellulose, titanium dioxide, and magnesium stearate after storage.

Microcrystalline cellulose is widely used in pharmaceutical formulations as a binder/diluent; its compatibility has been studied in several solid formulations (Bazzo et al., 2005; Ceschel et al., 2003; Stulzer et al., 2008). Magnesium stearate is employed as a lubricant; it is incompatible with several drugs (Daniel et al., 2013; Tita et al., 2011; Handbook of Pharmaceutical Excipients, 2006) but is compatible with others (Verma et al., 2004; 2005). Similar behavior was obtained in this study: no chemical interaction occurred in this binary mixture.

Degradation of VAL (approximately 9.17\%, Table I) occurs when it is mixed with crospovidone, a tablet disintegrant. In addition to the decrease in drug content, formation of a possible degradation product was observed, presumably due to chemical interactions between crospovidone and VAL (Figure 6). This finding suggests that crospovidone is incompatible with VAL under these conditions (high humidity and temperature). In previous reports (Ahuja et al., 2003) crospovidone, a cross-linked modified polyvinylpyrrolidone (PVP), was incompatible with several APIs, due to generation of hydrogen peroxide (Yue et al., 2009; Wu et al., 2011). Peroxides are reactive substances present in various excipients that can initiate radical chain reactions or react directly with drugs, inducing the formation of degradation products. A similar result was observed for the binary mixture of VAL with hypromellose (Figure 6). In this case, the concentration of VAL decreased and a new peak appeared in the chromatogram, which we attribute to a degradation product. Hydroxypropyl methycellulose, a coating agent and rate-controlling polymer for sustained release formulations, may react with the hydroxyl group of VAL (Dong et al., 2008).

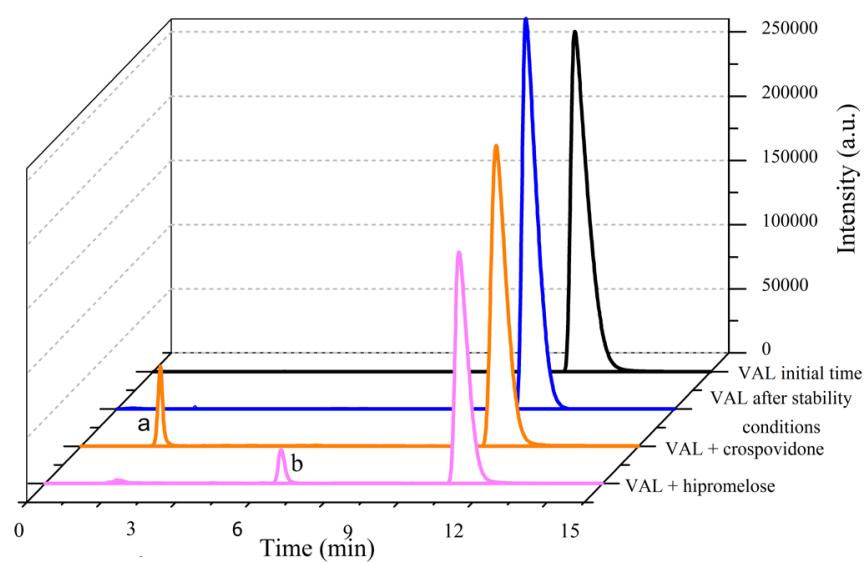

FIGURE 6 - HPLC chromatograms of VAL in binary mixtures with crospovidone and hypromellose ( $\mathrm{a}$ and $\mathrm{b}$ are degradation products).

Hypromellose and crospovidone degradation product peak areas are given in Table 1. These degradation products have not been identified or reported previously. Although VAL was incompatible with these two excipients, the final formulation would not be in direct contact with high humidity ( $75 \%$ RH). Furthermore, a wet granulation process must be avoided in VAL solid formulation.

These results demonstrate that excipient compatibility testing is essential for stable formulation development and for choosing between dry or wet granulation processes, as well as for controlling the final humidity of the formulation.

\section{CONCLUSION}

Different techniques were used to evaluate the stability and compatibility of VAL with pharmaceutical excipients. The results confirmed that HPLC is suitable for the evaluation of amorphous VAL-excipient interactions in the first stage of formulation. Though more laborious, 
HPLC is more reliable, due to the accurate results obtained using a pharmacopeia-validated stability-indicating method.

Based on the HPLC-UV results, most of the excipients tested (microcrystalline cellulose, titanium dioxide and magnesium stearate) were compatible with VAL. However, chemical interactions were inferred from a reduction in API concentration, and degradation products were detected when crospovidone or hypromellose was used. However, this study was performed using binary mixtures $(1: 1 \mathrm{w} / \mathrm{w})$, while the ratio in a formulation might be lower, reducing the degradation rate. In the case of hypromellose, this excipient is part of the formulation coating; thus, there is less contact with the drug, and the incompatibility might not be significant in tablets. However, pre-formulation studies using binary mixtures in equal proportions (1:1) are a useful procedure to detect the formation of degradation products in a new formulation.

A non-thermal compatibility study of an active substance should be combined with stability and assay determination with various excipients to determine the most appropriate excipient. Moreover, the stability of the drug when combined with other components should be evaluated, thus ensuring a safe and effective pharmaceutical formulation.

\section{ACKNOWLEDGMENTS}

The authors would like to thank the Fundação de Amparo a Pesquisa do Estado de Minas Gerais (FAPEMIG) for financial support (APQ-02805-10) and Prof. Dr. Doriguetto (Laboratory of Crystallography UNIFAL/MG) for the PXRD analysis.

\section{REFERENCES}

AGRAHARI, V.; KABRA, V.; GUPTA, S.; NEMA, R.K.; NAGAR, M.; KARTHIKEYAN, C.; TRIVEDI, P. Determination of inherent stability of valsartan by stress degradation and its validation by HPLC. Int. J. Pharm. Clin. Res., v.2, n.1, p.77-81, 2009.

AHUJA, S.; MILLS, K. Handbook of isolation and characterization of impurities in pharmaceuticals. San Diego: Academic Press, 2003. 414 p.

ALMEIDA, M.M.; LIMA, C.R.C.; QUENCA-GUILLEN, J.S.; FILHO, E.M.; MERCURI, L.P.; SANTORO, M.I.R.M.; KEDOR-HACKMANN, E.R.M. Stability evaluation of tocopheryl acetate and ascorbyl tetraisopalmitate in isolation and incorporated in cosmetic formulations using thermal analysis. Braz. J. Pharm. Sci., v.46, n.1, p.129-134, 2010.
BAZZO, G.C.; SILVA, M.A.S. Estudo termoanalítico de comprimidos revestidos contendo captopril através de termogravimetria (TG) e calorimetria exploratória diferencial (DSC). Braz. J. Pharm. Sci., v.41, n.3, p.315-322, 2005.

BLASKO, A.; DIOS, A.L.; NELSON, W.O.; AUSTIN, S.A.; KILLION, R.B.; VISOR, G.C.; MASSEY, I.J. Revisiting the solubility concept of pharmaceutical compounds. Monatsh. Chem., v.132, n.7, p.789-798, 2001.

CELEBIER, M.; KAYNAK, M.S.; ALTINOZ, S.; SAHIN, S. HPLC method development for the simultaneous analysis of amlodipine and valsartan in combined dosage forms and in vitro dissolution studies. Braz. J. Pharm. Sci., v.46, n.4, p.761-768, 2010.

CESCHEL, G.C.; BADIELLO, R.; RONCHI, C.; MAFFEI, P. Degradation of components in drug formulations: a comparison between HPLC and DSC methods. J. Pharm. Biomed. Anal., v.32, n.4-5, p.1067-1072, 2003.

DANIEL, J.S.P.; VERONEZ, I.P.; RODRIGUES, L.L.; TREVISAN, M.G.; GARCIA, J.S. Risperidone-solid-state characterization and pharmaceutical compatibility using thermal and non-thermal techniques. Thermochem. Acta, v.568, n.20, p.148-155, 2013.

DONG, Z.; CHOI, D.S. Hydroxypropyl methylcellulose acetate succinate: potential drug-excipient incompatibility. AAPS Pharm. Sci. Tech., v.9, n.3, p.991-997, 2008.

GIBSON, M. (Ed.). Pharmaceutical preformulation and formulation. 1.ed. Florida: CRC Press, 2004. 175 p.

INTERNATIONAL CONFERENCE ON HARMONIZATION. Stability testing of new drug substances and products, in: proceedings of the international conference on harmonization. Geneva: IFPMA, 2003. Available at: $<$ http://www.fda.gov/RegulatoryInformation/Guidances/ ucm128179.htm>. Accessed on: 13 Aug. 2013.

JULIO, T.A.; ZAMARA, I.F.; GARCIA, J.S.; TREVISAN, M.G. Compatibility of sildenafil citrate and pharmaceutical excipients by thermal analysis and LC-UV.J. Therm. Anal. Calorim., v.111, n.3, p.2037-2044, 2013.

KRISHNAIAH, C.; REDDY, A.R.; KUMAR, R.; MUKKANTI, $\mathrm{K}$. Stability- indicating UPLC method for determination of Valsartan and their degradation products in active pharmaceutical ingredient and pharmaceutical dosage forms. J. Pharm. Biomed. Anal., v.53, n.3, p.483-489, 2010. 
LATE, S.G.; BANGA, A.K. Thermal and non-thermal methods to evaluate compatibility of granisetron hydrochloride with tablet excipients. Pharmazie, v.63, n.6, p.453-458, 2008.

LEWINGTON, S.; CLARKE, R.; QIZILBASH, N.; PETO, R.; COLLINS, R. For the prospective studies collaboration. Age-specific relevance of usual blood pressure to vascular mortality: a meta-analysis of individual data for one million adults in 61 prospective studies. Lancet, v.360, n.9349, p.1903-1913, 2002.

LILTORP, K.; LARSEN, T.G.; WILLUMSEN, B.; HOLM, R. Solid state compatibility studies with tablet excipients using non thermal methods. J. Pharm. Biomed. Anal., v.55, n.3, p.424-428, 2011.

LOTUFO P.A. Stroke in Brazil: a neglected disease. Sao Paulo Med. J., v.123, n.1, p.3-4, 2005.

MURA, P.; FURLANETTO, S.; CIRRI, M.; MAESTRELLI, F.; MARRAS, A.M.; PINZAUTI, S. Optimization of glibenclamide tablete composition through the combined use of diffrencial scanning calorimetry and D- optimal mixture experimental design. J. Pharm. Biomed. Anal., v.37, n.1, p.65-71, 2005.

OLIVEIRA, M.A.; YOSHIDA, M.I.; GOMES, E.C.L. Análise térmica aplicada a fármacos e formulações farmacêuticas na indústria farmacêutica. Quím. Nova., v.34, n.7, p.1224$1230,2011$.

ROWE, R.C.; SHESKEY, P.J.; OWEN S.C. Handbook of pharmaceutical excipients, 1.ed. London: The Pharmaceutical Press, 2006. 430 p.

SLAVIO, H.N.; NOVAK, C.; MATOS, J.R. Thermal analysis and compatibility studies of prednicarbate with excipients used in semi-solid pharmaceutical form. J. Therm. Anal. Calorim., v.97, n.1, p.367-374, 2009.

STULZER, H.K.; RODRIGUES, P.O.; CARDOSO, T.M.; MATOS, J.S.R.; SILVA, M.A.S. Compatibility studies between captopril and pharmaceutical excipients used in tablets formulations. J. Therm. Anal. Calorim., v.91, n.1, p.323-328, 2008.
TITA, B.; FULIAS, A.; BANDUR, G.; MARIAN, E.; TITA, D. Compatibility study between ketoprofen and pharmaceutical excipients used in solid dosage form. $J$. Pham. Biomed. Anal., v.56, n.2, p.221-227, 2011.

USP 32: THE UNITED STATES PHARMACOPEIAL CONVENTION, 2009. The United States Pharmacopeia and National Formulary (USP 32-NF 27). Rockville: United States Pharmacopeial Convention, 2008. v.3.

VERMA, R.K.; GARG, S. Compatibility studies between isosorbide mononitrate and selected excipients used in the development of extended release formulations. J. Pharm. Biomed. Anal., v.35, n.3, p.449-458, 2004.

VERMA, R.K.; GARG, S. Selection of excipients for extended release formulations of glipizide through drug- excipient compatibility testing. J. Pharm. Biomed. Anal., v.38, n.4, p.633-644, 2005.

YUE, H.; BU, X.; HUANG, M.H.; YOUNG, J.; RAGLIONE, T. Quantitative determination of trace levels of hydrogen peroxide in crospovidone and pharmaceutical product using high performance liquid chromatography with coulometric detection. Int. J. Pharm. v.375, n.1-2, p.33-40, 2009.

WATERMAN, K.C.; ADAMI, R.C. Accelerated aging: prediction of chemical stability of pharmaceuticals. Int. J. Pharm., v.293, n.1-2, p.101-125, 2005.

WU, Y.; LEVONS, J.; NARANG, A.S.; RAGHAVAN, K.; RAO, V.M. Reactive impurities in excipients: profiling, identification and mitigation of drug-excipient incompatibility. AAPS Pharm. Sci. Tech., v.12, n.4, p.12481263,2011

Received for publication on $06^{\text {th }}$ November 2012 Accepted for publication on $09^{\text {th }}$ August 2013 